\title{
Narrative review of the evolution of lung transplant
}

\author{
George Makdisi, Alex R. Cedeño-Rodríguez \\ Department of Cardiothoracic Surgery, Albany College of Medicine, Albany Medical Center, Albany, NY, USA \\ Contributions: (I) Conception and design: Both authors; (II) Administrative support: Both authors; (III) Provision of study materials or patients: None; \\ (IV) Collection and assembly of data: Both authors; (V) Data analysis and interpretation: Both authors; (VI) Manuscript writing: Both authors; (VII) \\ Final approval of manuscript: Both authors. \\ Correspondence to: George Makdisi, MD, MPH, MS. Department of Cardiothoracic Surgery, Albany College of Medicine, Albany Medical Center, 40 \\ New Scotland Ave., Suite 192, Albany, NY 12206, USA. Email: gmakdisi@hotmail.com.
}

\begin{abstract}
Objective: To outline the important steps and major advances in the evolution of lung transplant in all its aspects and fields.

Background: The first successful human lung transplant was performed approximately six decades ago, but evolution has been slow. It was not until the past two decades that lung transplantation became a more routine procedure with predictable outcomes.

Methods: A comprehensive search of the medical literature using Ovid and PubMed search engines was conducted for progression of all aspects of lung transplantation, including surgical techniques, immunosuppression progression, donor selection criteria evolution, recipient criteria evolution, new technology used to support the patient prior and after transplant, along with donor organ management and the Lung Allocation Scoring (LAS) system variables and their impact on outcomes after lung transplantation.

Conclusions: Advancement has been multifactorial in all phases of lung transplantation: in the preoperative phase with better selection criteria, better nutrition, and better pulmonary and physical rehabilitation; in the perioperative phase with improvement of surgical techniques, immunosuppression drugs, development of mechanical circulatory support, and preservation technology; and in the postoperative phase with better understanding of immune rejection and better management of long-term complications. All these progressions have been fundamental to the current success of lung transplantation.
\end{abstract}

Keywords: Extracorporeal membrane oxygenation (ECMO); ex-vivo lung perfusion (EVLP); history; lung transplantation

Received: 02 March 2021; Accepted: 10 November 2021.

doi: $10.21037 /$ ccts-21-11

View this article at: https://dx.doi.org/10.21037/ccts-21-11

\section{Introduction}

Progression in lung transplantation has been slow, but outcomes have changed dramatically from a few days' survival in the first 20 years to excellent and more predictable outcomes nowadays. In 2019, the United Network for Organ Sharing (UNOS) reported an all-time record of 2714 lungs transplants in the USA, which is a $7.3 \%$ increase from 2018 and over 4,000 worldwide (1). In 2020 the number of lung transplant cases in the USA was affected by the COVID-19 pandemic and dropped to 2,539 lung transplants. Lung transplantation has progressed exceptionally over the past 60 years in all aspects, including surgical techniques, donor and recipient selection criteria, revolutionary progression in immunotherapy along with new technologies that have improved the quality of the donor lung and support the recipient in the preoperative period. All of this has resulted in a meaningful growth in lung transplantation and improved long-term survival. In this review we will focus on the major steps of this evolution in all areas of lung transplantation.

We present the following article in accordance with the Narrative Review reporting checklist (available at https:// ccts.amegroups.com/article/view/10.21037/ccts-21-11/rc). 

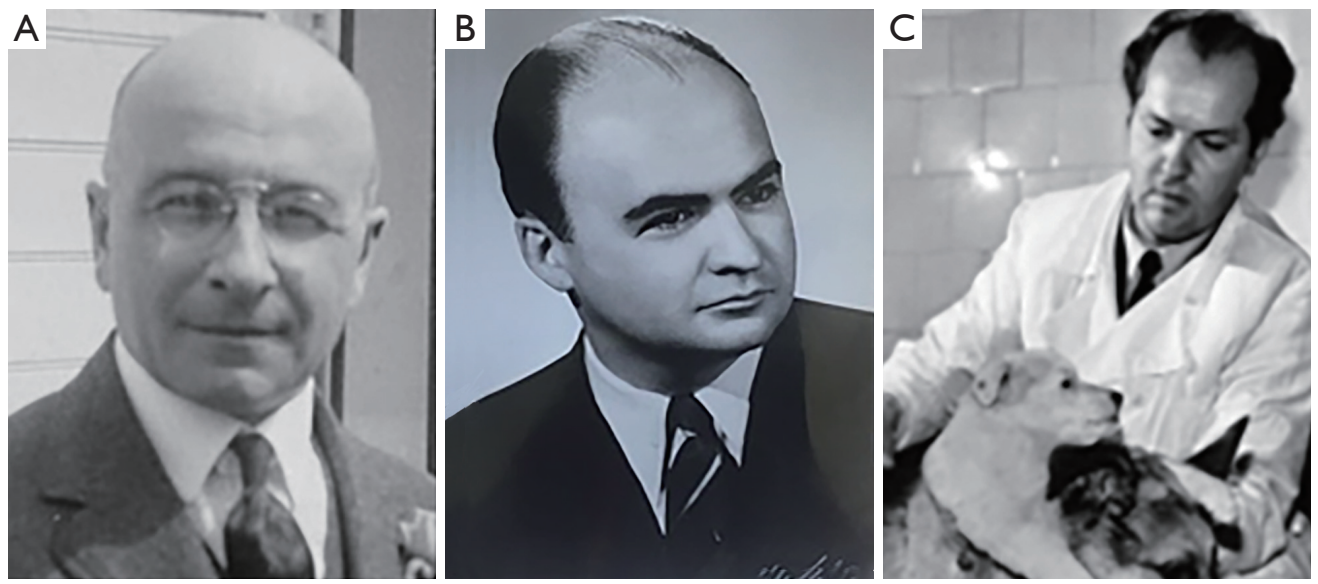

Figure 1 Pioneers of experimental lung transplantation. (A) Alexis Carrel MD, "1912 Nobel Prize in Physiology or Medicine”. (B) Henri Metras MD. (C) Vladimir Demikhov MD.

\section{Methods}

A comprehensive search of the medical literature using Ovid and PubMed search engines was conducted for progression of all aspects of lung transplantation, including surgical techniques, immunosuppression progression, donor selection criteria evolution, recipient criteria evolution, new technology used to support the patient prior and after transplant, along with donor organ management and the Lung Allocation Scoring (LAS) system variables and their impact on outcomes after lung transplantation.

\section{Animal models and technical feasibility phase}

The first period includes the preclinical and laboratory phase, which was approximately six decades long (1900s to early 1960s). It was a period of hard work and commitment to configure the anatomy, physiology and best surgical techniques for lung transplantation. Based on his excellent work on blood vessel anastomosis and on organ reimplantation and transplantation, Alexis Carrel (Figure 1) was the first to report a lung transplant surgery when he performed an en-bloc heart and lung transplant to a cat in 1907 (2). In 1934, Alex Carrel, in collaboration with Charles Lindbergh, developed the first "functional pump oxygenator" (3).

Four decades after Carrel's first attempt, Vladimir Demikhov (Figure 1) was performing lung transplantations with animal models in his laboratory, including en-bloc heart and lungs and right lower lobe transplantation in dogs in 1946. In 1947, he was able to successfully perform two isolated lung transplants; however, survival was 1 and 4 weeks, respectively (4).

In 1950, Henri Metras (Figure 1) reported the first successful double-lung transplant in a dog. His surgical description included three major technical advances: the first bronchial artery anastomosis to the subclavian artery, main bronchial anastomosis, and a left atrium to pulmonary vein anastomosis; all these techniques are still being used (5).

As part of the first period in lung transplantation, it is also worthwhile noting that Juvenelle $e t$ al. performed the first lung reimplantation, while studying the autonomic nerve supply in the lung for a potential treatment of asthma (6). It is also worthwhile mentioning that the concept and importance of immune rejection was still not well comprehended until 1944, when Medawar introduced it during his studies of skin graft rejection (7). This will be discussed in detail in immunosuppression section.

\section{Major milestones in the second phase of human lung transplantation}

The second period in lung transplantation started in 1963 when James Hardy (Figure 2) performed the first human lung transplantation. He implanted a left lung to a patient suffering from cancer. The patient survived the operation but died 18 days later due to renal failure (8). Four weeks later, Magovern and Yates reported the second human left lung transplant, which was another surgical success, but the patient only lived for 7 days (9).

Over the next 20 years only 44 lung transplants were performed and most of the patients died within the first 


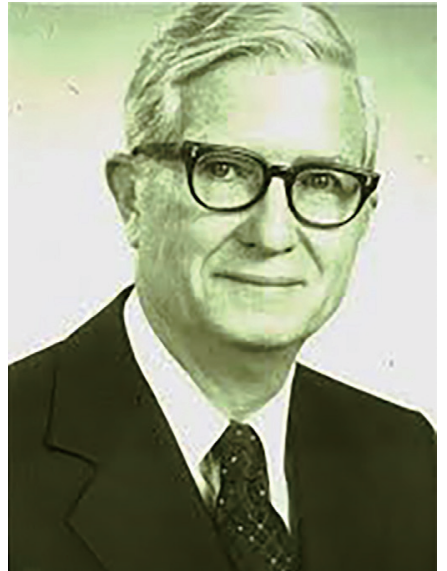

Figure 2 Dr. James Hardy, who performed the first human lung transplantation.

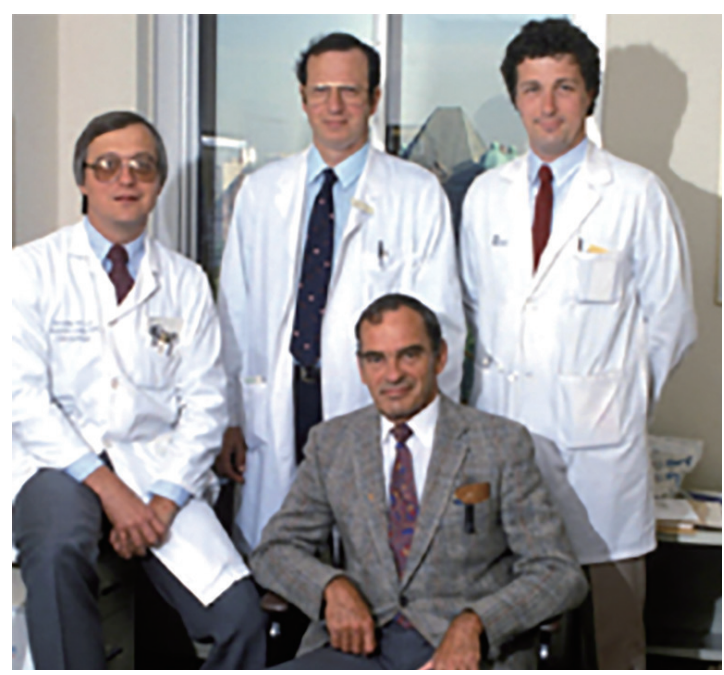

Figure 3 Toronto Lung Transplant Group. From left to right: Griff Pearson MD, Tom Todd MD, Joel Cooper MD, and sitting, Alec Patterson MD.

month after operation; the longest survival of 10.5 months was reported by Derom et al. in 1968, but the patient spent most of that time in the hospital and ultimately died of chronic organ rejection (10).

Combined heart and lung transplant had the same rough start; when Denton Cooley performed the first human en-bloc heart and lung transplant in 1968, the patient survived for only $14 \mathrm{~h}$, but it was considered as proof of concept because it showed that the procedure was feasible and could be successful (11). Five months later, Clarence Walton Lillehei reported the second combined heart-lung

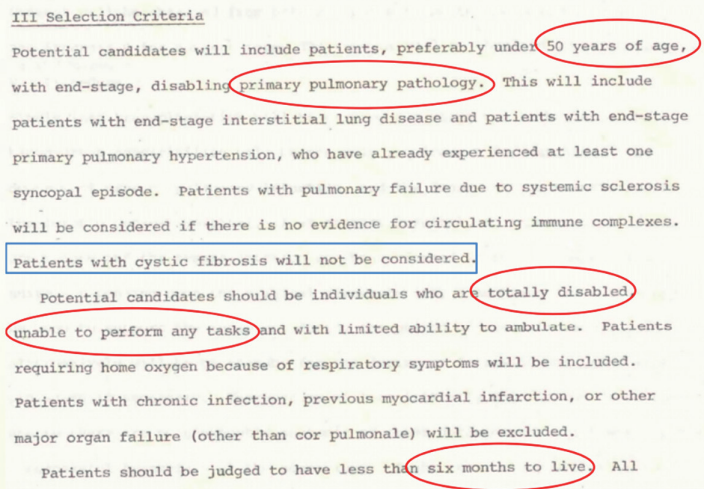

Figure 4 Toronto Lung Transplant Group selection criteria form, 1982.

transplant, and the patient lived for 8 days (12).

\section{Lung transplant reset, reboot and survival success}

Driven by the success of cyclosporine in kidney and liver transplant, the Stanford team, led by Drs. Norman Shumway, Bruce Reitz, and John Wallwork, performed what is considered the first long-term successful heart and bilateral lung transplant in 1981 (13). In parallel the Toronto Lung Transplant Group led by Joel Cooper and Alexander Patterson (Figures 3,4) had also changed the immunosuppression protocol and in 1986 were able to perform the first successful long-term single-lung transplant for a pulmonary fibrosis patient, known as lung transplant \#45, who lived for 7 years (14). Soon after, they reported a case of bilateral lung transplant in an emphysematous patient who lived for 16 years (15).

During this period, multiple other concepts in the field were challenged; at that time, bilateral lung transplantation was considered the only viable option for patients with emphysema, the rationale being that when a singlelung transplant was performed, the non-transplanted lung became hyperinflated, affecting the function of the transplanted lung. In 1989 this theory was challenged by Mal et al. who reported a single-lung transplant in a patient with emphysema without subsequent significant hyperinflation (16).

Driven by the success achieved from partial transplant of other organs, Starnes performed the first successful living-donor lobar lung transplantation (LDLLT) when 
he replaced the right lung of a 12-year-old girl with her mother's right lower lobe, followed by bilateral lung transplant using two lower lobes of two different donors 1992 (17). It is worthwhile mentioning that the world's first lobar lung transplant was first attempted in Japan in 1966 by Shinoi et al. at Tokyo Medical College; the patient survived, but the transplanted lobe had to be removed on postoperative day 18 (18).

The concept of inverted lung transplantation was first described in a cadaveric lung transplantation by the Jean Paul Couetil and Alain Carpentier team in 1997 (19,20). However multiple nonstandard configurations of LDLLT as singlelobe transplants, native upper lobe sparing, inverted along with combine sparing and inverted lobes could be credited to Hiroshi Date and the Kyoto University team $(21,22)$.

\section{Other major surgical technical achievements}

The technical aspects of both single- and double-lung transplants have evolved over the years. Advancement in lung transplantation was initially troublesome mainly due to the technical aspect of bronchial anastomosis. The poor healing of the bronchial anastomosis resulted in high morbidity and mortality rates due to anastomotic dehiscence. Initially, double-lung transplant was performed with an en-bloc approach with a single tracheal anastomosis. This technique had a high risk of tracheal dehiscence for which the anastomosis site was shifted to the level of the main stem bronchi. This technique was first described by Metras in 1950 (5), and later re-described by Noirclerc (23) and promoted by Cooper and Pasque in 1990 (24). Other techniques, such as telescoped bronchial anastomosis, were initially accepted due to the work of Veith et al. (25); this shifted towards end-to-end airway anastomosis when Garfein et al. proved it had less anastomotic stenosis and complication rates than telescoped bronchial anastomosis (26).

The lungs are the only solid organ that is transplanted without a systemic arterial blood supply. This peculiarity leads to several unique complications, including bronchial ischemia, granulation formation, mucosal sloughing, bronchial dehiscence, and bronchial stenosis. In order to reduce such complications, bronchial arterial revascularization (BAR) emerged as a technique to reduce the incidence of airway ischemia. It was first described in a human lung transplant by Haglin et al. (27) using the same technique that Metras described in 1950 on his animal models (5).

Since then, different techniques have been described for BAR, including greater saphenous vein conduit, internal mammary artery conduit, and donor aortic patch containing the origin of both bronchial arteries sewn directly to the recipient aorta (28-30). Even though BAR has been proven to be effective in decreasing bronchial anastomotic complications and has clinical advantages, including long-term survival, less infection rate and primary graft dysfunction (PGD), it is not widely used due to the technical challenges $(31,32)$.

The surgical incision and the surgical approach have also evolved. Double-lung transplant used to be performed via sternotomy for a long period of time, but transitioned to a clamshell incision, which allows for better access to the posterior mediastinum for bronchial anastomosis. Although the clamshell technique was first described by Kortz in 1958 (33), it was not until 1990 that it was first reported being used for lung transplants $(23,24)$. Due to healing complications, surgeons slowly shifted toward using a bilateral anterolateral thoracotomy, which allows excellent exposure without the need for sternal division.

\section{Lung transplant and the rise of machines}

\section{Extracorporeal membrane oxygenation (ECMO) use in lung transplantation}

As formerly mentioned, Alex Carrel and Charles Lindbergh developed the first "functional pump oxygenator" (3), which is considered to be the very first technology used for the development of the cardiopulmonary bypass (CPB) machine, ECMO, and ex-vivo support. The use of these later devices was a game changer in lung transplant surgery. Even though the first successful single-lung transplant and subsequent single-lung transplantations were usually performed without CPB (14), the en-bloc lung transplant used to be performed via a median sternotomy on $\mathrm{CPB}$ with tracheal anastomosis. The shift to bilateral sequential lung transplant with anastomosis at the level of the main bronchus showed the possibility to perform lung transplantation without $\mathrm{CPB}$, especially in patients without pulmonary hypertension. This led to the pursuit of different ways to support the patient during the procedure and in the perioperative period with ECMO. ECMO is now used frequently in all steps of lung transplantation. Currently, there is sufficient data to favor the use of ECMO in patients with severe PGD $(34,35)$. The progression in venovenous (VV) ECMO support and increased ECMO experience have led to better outcomes, along with increasing belief that better physical 
condition of the patient before transplant will lead to better outcomes. These factors led to the use of VV ECMO bridge-to-transplant, giving patient time to be optimized and reconditioned while waiting for suitable lungs (36-38). Note that the first use of ECMO support as a bridge was in 1977 when Frank Vieth reported the use of VV ECMO as a bridge-to-transplant for 3 days, although the patient died after 10 days postoperative from a lung infection (39). Later, venoarterial (VA) ECMO was introduced to replace $\mathrm{CPB}$ as intraoperative support in patients who needed cardiac and pulmonary support. This was first reported in 2002 by Arpad Pereszlenyi (Vienna Group) who used it in a patient with pulmonary hypertension (40). The superiority of VA ECMO over CPB has been reported in multiple investigations since then $(41,42)$.

\section{Donation after cardiac death (DCD), ex-vivo lung perfusion (EVLP), and organ care system (OCS)}

Even though the first human lung transplant used a DCD donor, almost all lung transplants performed in the following 30 years were done using brain-dead donors. This concept was driven by the need to increase the lung donor pool and was feasible because of the notion that lung tissue could remain viable for a few hours after cardiac death. It was proven by Egan et al. when they reported successful lung transplantations in animals using dead dogs' lungs up to $4 \mathrm{~h}$ after their death (43). Later, in 1995 Love et al. were able to replicate this success in humans by performing the first successful single-lung transplantation from a controlled DCD donor $(44,45)$. The evolution and reliability of this technology is obvious when current data outcomes from DCD donors show no major difference in outcomes when compared with brain-dead donors $(46,47)$.

The traditional method of transportation and preservation of lungs until the time of implantation is to keep them inside a cooler full of ice (outside cooling), aiming to keep temperature around $4{ }^{\circ} \mathrm{C}$; however, there is no way of verifying if the temperature remains stable during transportation, and another uncertainty is the temperature discrepancy between the outer surface of the lung and the inner lung tissue. Different techniques to overcome these have been attempted, such as using continuous perfusion of the lung (with cold perfusate) up to the time of transplant or what used to be called keeping the "heart and lungs alive" and functioning outside the body, which was suggested by Robicsek et al. $(48,49)$. Using autoperfusion of the heart and lungs as a method of preservation to allow distant procurement was introduced in early 1980 by Robert Hardesty and Bartley Griffith (50). Using EVLP in DCD donors was introduced by Stig Steen and his team from Lund University in Sweden when they successfully performed a single-lung transplant from an uncontrolled DCD donor (Maastricht Categories I and II) using an EVLP support donor lung prior to transplant (51). This was a major accomplishment in lung transplantation, not only because it made DCD a safer option, but also helped increase the donor pool. The EVLP technology was enhanced and popularized by the Toronto Group, reporting similar survival rates when compared with conventional transplantation with similar physiologic and functional outcomes (52).

The use of EVLP has expanded the donor pool; according to the International Society of Heart and Lung Transplantation (ISHLT) registry, 20\% of all DCD donors are transplanted after ex-vivo evaluation (53). EVLP also helps in the evaluation and reconditioning of marginal lungs, which has been proven and supported by multiple studies that have shown similar survival and PGD rates when compared with non-EVLP lungs. The use of EVLP has also made it possible to safely expand the time for implantation to more than just a few hours (54-56).

The EVLP system (Figures 5,6) provides a window of time to transport, evaluate and recondition the lungs outside the donor body prior to transplantation. In this case the lungs are transported on ice, then connected to the EVLP device to be evaluated and reconditioned in the donor hospital $(57,58)$.

OCS (Figure 7) is a newer method of preserving, assessing and transporting lungs; the lungs are placed on OCS at the donor hospital, which allows the lungs to be preserved in warm physiologic conditions and ventilated during this time, while during transport and assessment the vascular resistance and airway pressures can be monitored. OCS minimizes the cold ischemia time and enables assessment and reconditioning of standard and borderline donor lungs, as proven by multiple studies using normal (INSPIRE trial) and extended donor criteria (EXPAND trial) (59-61). In 2019 OCS received FDA approval (62).

\section{Immunosuppression and lung transplant}

The current success of organ transplantation has been the result of research of investigators and scientists in many medical disciplines, but mainly by the exceptional work of pharmacists, immunologists, and hematologists. The immunosuppressive regimen chosen by Hardy et al. consisted 


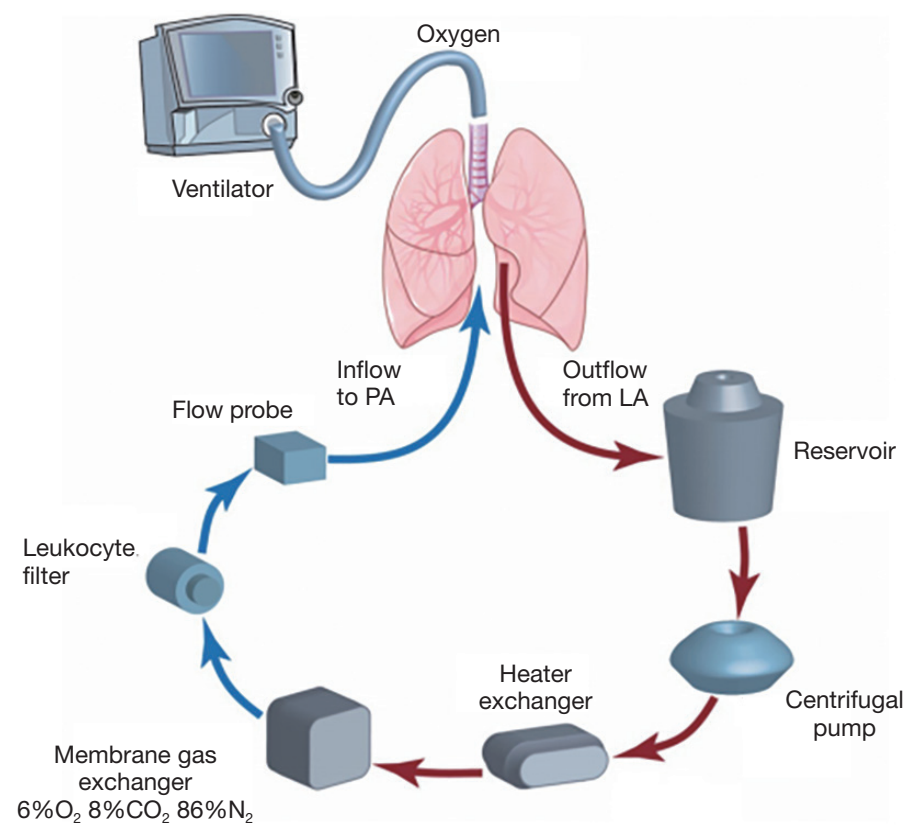

Figure 5 EVLP circuit with permission of Makdisi and Wozniak (57). EVLP, ex-vivo lung perfusion.

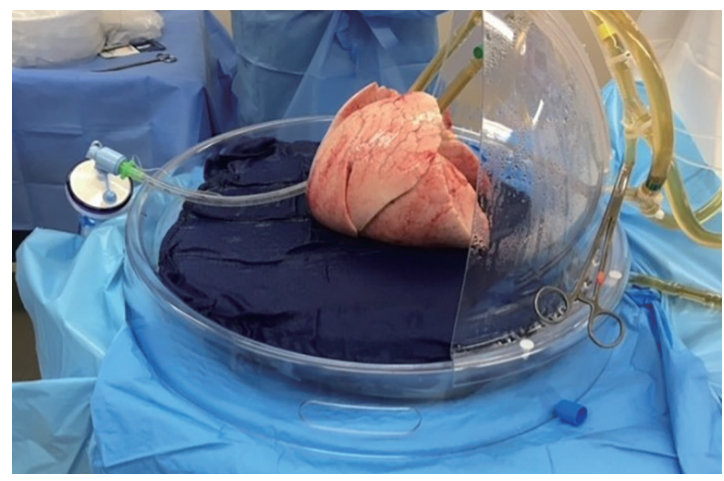

Figure 6 EVLP circuit [with permission of Makdisi et al. (58)]. EVLP, ex-vivo lung perfusion.

of preoperative thymic radiation with cobalt therapy directed to the mediastinum and postoperative immunosuppression with azathioprine and prednisone (8). Immunosuppression management during and after lung transplantation continues to develop, with more protocols and agents available for use, allowing for more individualization of immunosuppressive therapy. Immunosuppression in lung transplant, as with any organ transplant, consists of induction therapy to deplete the immune system in the immediate post-transplant period and to decrease the early interaction between the new lungs and the recipient immune system, and maintenance therapy to maintain long-term graft survival (there are different agents and different protocols that will be discussed in a different article in the series). Here we will discuss the major steps in the evolution of immunosuppression.

Although skin grafts have been used for hundreds of years, the concept and importance of immune rejection was still not well understood until 1944, when Peter Medawar (Figure 1A) introduced the concept from his studies of skin graft rejection (7). Corticosteroids have been a constant in immunosuppressive regimens since the beginning of solid organ transplantation, which Rupert Billingham found to prolong survival of skin homografts in rabbits (63). The first use of for corticosteroids in human solid organ transplant is credited to Hume et al. when they reported using corticosteroids in nine cases in the early 1960s (64); Willard Goodwin later reported using corticosteroids to reverse acute rejection in a living-donor kidney transplant recipient $(65,66)$ and in 1963 Thomas Starzl, confirmed the efficacy of corticosteroids and the "almost miracle" effect (67).

Total body radiation used in the laboratory for solid organ transplant is often credited to William Dempster, who also treated dog homograft recipients with cortisone $(68,69)$. However, Jean Hamburger (70) and René Küss (71) independently reported performing six successful transplants between 1959 and 1962 in non-twin recipients prepared by total body irradiation. 

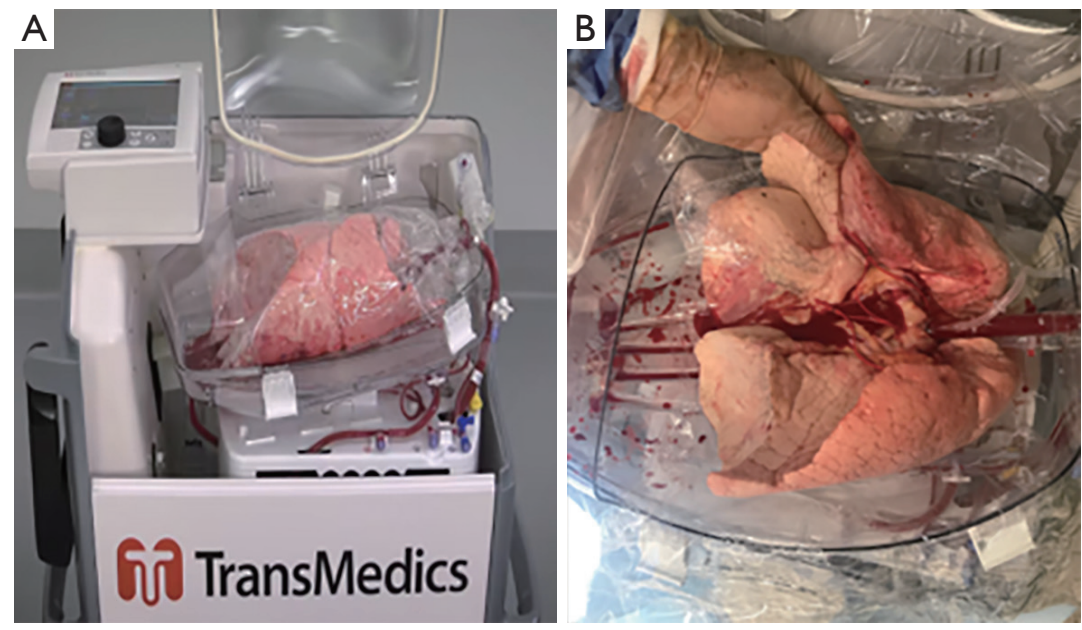

Figure 7 OCS lung. (A) Lungs under evaluation and reconditioning using OCS prior transplantation. (B) Lungs connected to OCS system prior evaluation process and transportation. OCS, organ care system.

In 1956 Gertrude Elion and George Hitchings, "1988 Nobel Prize winners in Physiology or Medicine", codiscovered and developed 6-mercaptopurine (6-MP) and azathioprine, both being purine analogs. Azathioprine is metabolized to 6-MP both in vitro and in vivo (72), and 6-MP was the first used in an animal transplant in 1959 when Schwartz and Dameshek demonstrated that 6-MP prolonged skin allograft survival in rabbits (73). This was the beginning of chemical immunosuppression in transplantation. Based on these studies, Zukoski et al. (74) and Roy Calne (75) independently introduced 6-MP in their preclinical studies of a canine kidney transplant model. However, it was rapidly proven that azathioprine could prolong renal allograft survival when given with corticosteroids (76).

After it was shown in human kidney recipients that the addition of antilymphocyte globulin to azathioprine and prednisone improved treatment efficacy (77), Derom used this immunotherapy regimen for the patient who survived for 10 months in 1967 (10).

Cyclosporine was discovered in Norway in 1969 by Dr. Hans Peter Frey, and initially developed as a new antibiotic drug; however, its biological effects and the discovery of its immunosuppressive characteristics without major cytotoxicity by Drs. Thomas Starzl, Jean-François Borel and Hartmann Stähelin (78-80), led to the use of cyclosporine in a human transplant in 1978, when it was used for the first time in human kidney transplantation to treat posttransplant organ rejection (81). Inspired by the success of cyclosporine in kidney and liver transplant, in 1981 Stanford University gained US Food and Drug Administration (FDA) approval for the use of cyclosporine in clinical heart-lung transplantation, and the first successful transplant of the heart and both lungs was performed by Bruce Reitz and John Wallwork (13). This was in fact the first long-term success for any kind of lung transplant. Cyclosporine was approved by the FDA in 1983 and almost immediately Joel Cooper and the Toronto Lung Transplant Group changed their immunosuppression protocol to include cyclosporine and were able to perform the first successful long-term single-lung transplant in 1983 (14).

Tacrolimus (FK506) was originally discovered in 1984 and received FDA approval in $1994(82,83)$. Trials revealed that patients treated with tacrolimus experienced significantly less acute rejection, and lymphocytic bronchitis was also less frequent among patients receiving tacrolimus compared with those receiving cyclosporine (84). Tacrolimus usage was found to be associated with a significantly reduced risk for bronchiolitis obliterans syndrome (BOS) grade $\geq 1$ at 3 years when compared with cyclosporine, despite a similar rate of acute rejection. However, no survival advantage was detected (85-87). Currently, tacrolimus is the most popular calcineurin inhibitor in use, while mycophenolic acid is the dominant purine synthesis inhibitor used (88).

Since then, great progress has been made in developing immunosuppression regimens to prevent acute and chronic rejection of the lung allograft while also aiming to reduce the risk of opportunistic infection, a major side effect of immunosuppression. Early detection and treatment of graft dysfunction, infection, and chronic lung allograft dysfunction (CLAD) are essential for longer graft survival. 
CLAD remains a major cause of morbidity and mortality following lung transplantation. BOS is the most common form of CLAD (65-75\% of all CLAD cases) and restrictive allograft syndrome is the second most common form $(89,90)$. Traditional diagnosis of BOS and CLAD used to be by pulmonary function test, bronchoalveolar lavage (BAL), transbronchial biopsy/conventional pathology, and radiologic findings $(91,92)$. Although there is no treatment currently available to reverse CLAD after diagnosis, early identification allows proactive and targeted strategies to reverse the progression of the disease before irreversible allograft damage occurs $(93,94)$. Nowadays, there are new revolutionary methods of early detection and diagnosis of CLAD using biomarkers via microarrays or RNA sequencing technology of samples collected from blood or BAL, including gene expression profiling, blood mRNA and miRNA transcriptome (95-97). For the future, genetic risk profiling of lung transplant recipients might be a promising approach to identifying patients at low risk of developing acute rejection and CLAD, which will probably lead to personalized immunosuppressive treatment with reduction of immunosuppressive treatment or the number of medical appointments, thus improving both health care efficacy, and quality of life (98).

\section{Development of the organ donation and transplantation system in the USA}

Organ transplantation requires collaboration among three different organizations: the donor hospital, the transplant center, and the organ procurement organization (OPO). Up until the mid-1970s, individual transplant centers and the local OPO used to manage all aspects of organ recovery. However, as there was no system to expand the availability of donor organs beyond the local OPO, the allocation was mainly restricted to only local patients. This resulted in transplant teams being unable to locate a compatible recipient in adequate time, leading to significant loss of good donor organs. In 1968, a scientific organization known as the Southeast Organ Procurement Foundation (SEOPF; now known as the American Foundation for Donation and Transplantation) was formed to enhance access to transplantation, improve quality and outcomes, and increase successful organ donation by facilitating collaboration between transplant centers and professionals, providing education, training, and sharing of best practices. In 1977, SEOPF implemented the first computer-based organ matching system, named UNOS $(99,100)$.
With the promising outcomes of solid organ transplants, the number of transplant candidates and transplant centers were significantly increasing, so there was an urgent need of a nationwide system to collect data and coordinate organ allocation. In 1984, the US Congress passed the National Organ Transplant Act (NOTA) (PL 98-507) (101), which established the framework for an Organ Procurement and Transplantation Network (OPTN) to ensure the fair and efficient allocation of donor organs. It also resulted in the creation of the Scientific Registry of Transplant Recipients (SRTR) to evaluate the scientific and clinical status of patients' post-transplant. UNOS received a federal contract to operate both OPTN and SRTR to maximize the appropriate use of a deceased person's organs. The organizations role was also to establish a system to collect, store, analyze and publish data pertaining to the recipient waiting list, organ matching and transplants. In 1992, UNOS prepared the first-ever comprehensive report on transplant survival rates for all active US transplant centers (102). This data led to the establishing of objective outcome criteria, to assess and investigate underperforming transplant programs. Programs with lower-than-expected survival rates are then reviewed by a UNOS committee (103). In 2006, UNOS launched DonorNet, an internet-based system to notify transplant hospitals of newly donated organs for compatible candidates (99).

\section{History of the donor Lung Allocation Scoring (LAS) system}

The development of the donor selection and matching system for lung allocation in the USA has been a complex, and at times, controversial process. The policy requirements instituted in the 1990s by OPTN was very simple: the donor lungs were allocated based on $\mathrm{ABO}$ match, the recipient residing within a 500-mile range of the donor organ/ transplant center, and the amount of time that candidates had accrued on the waiting list in the local OPO. This basic system resulted in low numbers of lung transplantations and increasing numbers of deaths of eligible recipients on the waiting list, because it did not account for the recipient's severity of disease or prognosis, nor lung failure pathology. In 1995 OPTN recognized the clinical significance of idiopathic pulmonary fibrosis by giving it an extra 90-day credit on the waiting list compared with other pathological presentations (104).

In 2005 the OPTN changed the allocation system for lung transplantation in the USA by moving toward the LAS 
system for lung recipients, the score for which is calculated from estimates of survival probability while on the lung transplant waiting list and following transplantation. Being a system intended to allocate lungs based on medical urgency and post-transplant survival, LAS is supposed to shorten the waiting time for very sick patients on the waiting list. In the years following implementation of the LAS system, wait-list times decreased, and the mean LAS of transplant recipients increased, consistent with a greater urgency for transplantation; the total number of patients transplanted also increased (105). In a retrospective study, Egan et al. compared the data of listed patients listed between the 5 years prior to LAS implementation [2000-04] and the 5 years after [2006-11] and as expected there was significant decrease in wait-list deaths from 500/year to 300/year, the distribution of recipient diagnoses also changed with significantly with more patients with fibrotic lung disease receiving transplants and the age of recipients also increased significantly (106).

Although the development of the system was complex and controversial it was quickly adopted by other countries system $(107,108)$. In 2020 the USA implemented an update of the LAS to better cope with patients with pulmonary hypertension, and that was refined in 2021 (109-111).

\section{Recipient selection evolution}

The appropriate selection of lung transplant recipients is an important determinant of overall outcome and has experienced major evolution over the years. In the early days of lung transplantation, recipients were often ventilatordependent, malnourished or had steroid-related myopathy and osteoporosis. The patient's candidacy used to be made by a few members of each transplant center without well-defined criteria, but with the surge in transplant volume, transplant institutions started to develop criteria for recipient's candidacy that were constantly modified. In the late 1980s and early 1990s, the important value of preoperative pulmonary rehabilitation and improved general physical condition was recognized, and currently most lung transplantation recipients are ambulatory. Wildevuur and Benfield (12) reviewed the first 23 human lung transplants performed by 20 surgeons, finding only one patient who survived more than 30 days. The majority of those patients presented with advanced cancer or were labeled as having terminal or preterminal conditions, conditions now considered absolute contraindication for transplant (112). In their research form for lung transplant application, the
Toronto Lung Transplant Team in 1982 set well-defined recipient selection criteria (Figure 4), with lung recipient candidates preferably be under 50 years of age, with primary pathology of the lung (excluding cystic fibrosis), unable to perform tasks due to their condition, and judged to have less than 6 months of life expectancy. These patients were recruited as experimental transplant recipients. Those with chronic infection, history of previous myocardial infarction, or another major organ failure were excluded (113).

For some time thereafter, many practitioners considered single-lung transplantation to be inappropriate for patients with emphysema due to the assumption that there would be dynamic hyperinflation of the native lung after transplantation. However, that theory was disproven in 1989 when Mal et al. demonstrated the feasibility of single-lung transplant in patients with emphysema without contralateral hyperinflation (16).

In 1998 the American Society for Transplant Physicians, the American Thoracic Society, the European Respiratory Society and the ISHLT organized a committee of international experts to provide a consensus opinion regarding the appropriate timing of referral for transplantation and listing of candidates for lung transplantation. This was the first international consensus of lung transplantation candidate selection (114). The goal of these recommendations was to assist physicians in appropriately identifying patients who are the most likely to benefit from lung transplantation, though they were largely based on expert opinion rather than being evidence based. The pulmonary council of ISHLT took the lead and updated these guidelines in 2006 and $2014(115,116)$ and will be discussed in a different article in this series.

\section{Transplant team concept}

The lung transplant procedure technically takes several hours between evaluation and transplantation. However, the transplant process itself is long, meticulous, and may take weeks or months to assess the patient's candidacy. In addition, post-transplant recovery can take months, even a year or more, as lung transplant recipients are vulnerable to many problems and need continuous adjustment of medications following transplant to prevent infection or organ rejection. Ensuring a good outcome requires a team built of healthcare professionals trained in multiple specialties working together to ensure favorable outcomes. The providers may include pharmacists, pulmonologists, surgeons, nutritionists, physical therapists, nurses, social 


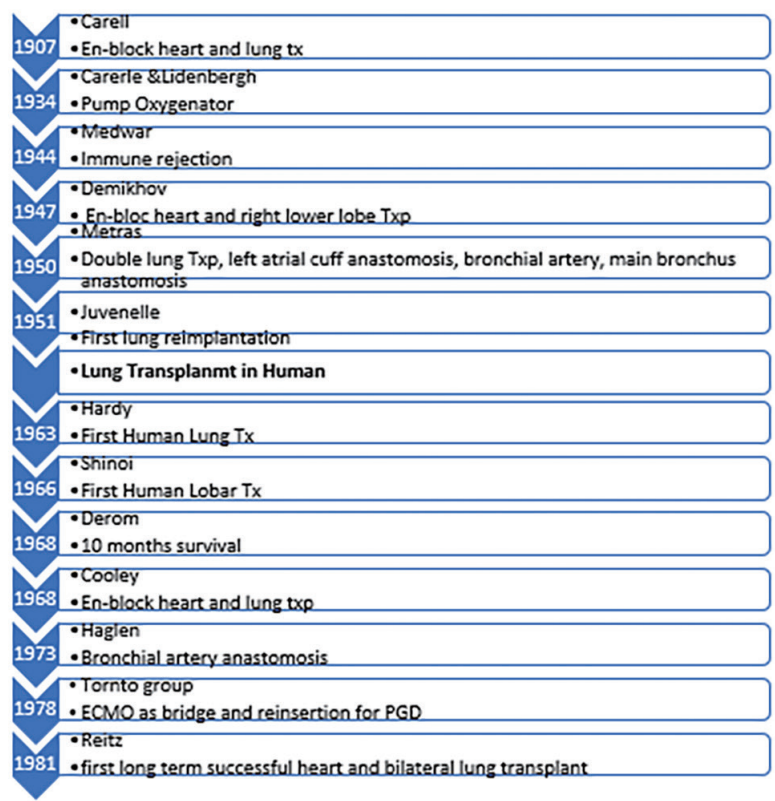
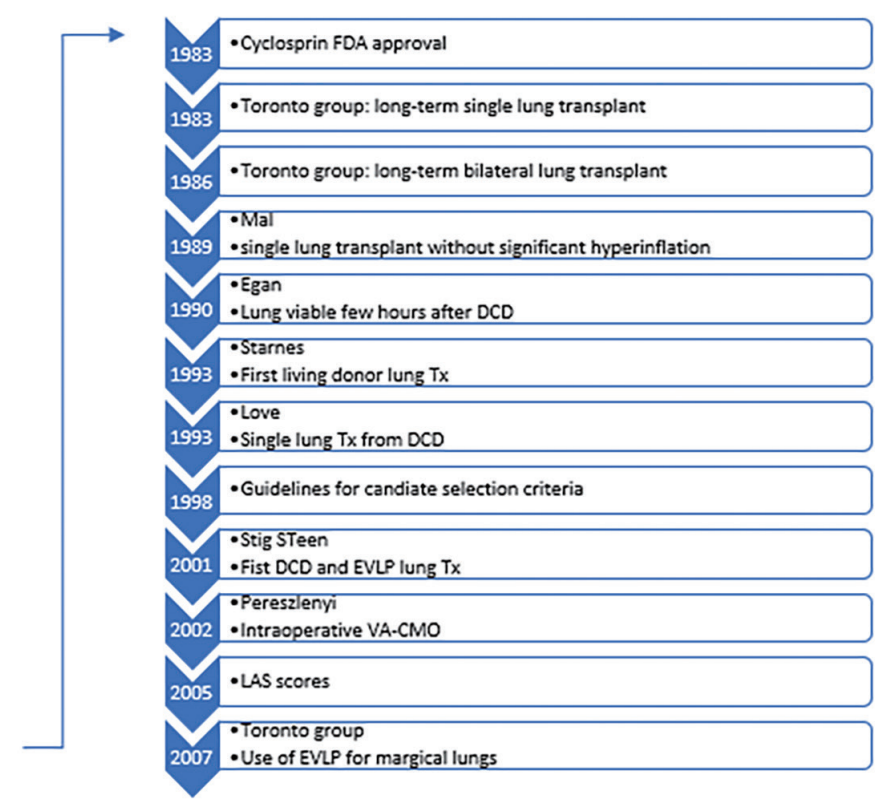

Figure 8 Landmarks of lung transplant history. DCD, donation after cardiac death; ECMO, extracorporeal membrane oxygenation; EVLP, ex-vivo lung perfusion; LAS, Lung Allocation Score; Tx, transplant.

workers, and transplant coordinators.

\section{Summary}

It is an understatement to say that lung transplant had evolved tremendously in the past 60 years: surgical techniques have been improved, selection criteria have been modified, and new technologies had emerged to improve the quality of the donor lung. All of this, combined with the introduction of mechanical circulatory support, has resulted in a meaningful growth in lung transplantation and improved long-term survival. Figure 8 is good summary of the major landmarks of this evolution.

\section{Acknowledgments}

Funding: None.

\section{Footnote}

Provenance and Peer Review: This article was commissioned by the editorial office, Current Challenges in Thoracic Surgery, for the series "Lung Transplant: Current Status and Challenges". The article has undergone external peer review.

Reporting Checklist: The authors have completed the
Narrative Review reporting checklist. Available at https:// ccts.amegroups.com/article/view/10.21037/ccts-21-11/rc

Peer Review File: Available at https://ccts.amegroups.com/ article/view/10.21037/ccts-21-11/prf

Conflicts of Interest: Both authors have completed the ICMJE uniform disclosure form (available at https://ccts.amegroups. com/article/view/10.21037/ccts-21-11/coif). The series "Lung Transplant: Current Status and Challenges" was commissioned by the editorial office without any funding or sponsorship. GM served as the unpaid Guest Editor of the series and serves as an unpaid Editorial Board Member of Current Challenges in Thoracic Surgery from May 2020 to April 2022. The authors have no other conflicts of interest to declare.

Ethical Statement: The authors are accountable for all aspects of the work in ensuring that questions related to the accuracy or integrity of any part of the work are appropriately investigated and resolved.

Open Access Statement: This is an Open Access article distributed in accordance with the Creative Commons Attribution-NonCommercial-NoDerivs 4.0 International License (CC BY-NC-ND 4.0), which permits the non- 
commercial replication and distribution of the article with the strict proviso that no changes or edits are made and the original work is properly cited (including links to both the formal publication through the relevant DOI and the license). See: https://creativecommons.org/licenses/by-nc-nd/4.0/.

\section{References}

1. Available online: https://optn.transplant.hrsa.gov/data/ view-data-reports/national-data/\# (Accessed 8/8/2021).

2. Carrel A. The surgery of blood vessels, etc. Johns Hopkins Hosp Bull 1907;18:18-28.

3. Carrel A, Lindbergh CA. The culture of whole organs. Science 1935;81:621-3.

4. Demikhov VP. Transplantation of vital organs in experiments. Mosco: Medgiz, 1960.

5. Metras H. Note preliminaire sur greffe totale du poumon chez le chien. Comp Renal Acad Sci 1950;231:1176-7.

6. Juvenelle AA, Citret C, Wiles CE Jr, et al. Pneumonectomy with replantation of the lung in the dog for physiologic study. J Thorac Surg 1951;21:111-5.

7. Medawar PB. The behaviour and fate of skin autografts and skin homografts in rabbits: A report to the War Wounds Committee of the Medical Research Council. J Anat 1944;78:176-99.

8. Hardy JD, Webb WR, Dalton ML Jr, et al. Lung homotransplantation in man. JAMA 1963;186:1065-74.

9. Magovern GJ, Yates AJ. Human homotransplantation of left lung: report of a case. Ann N Y Acad Sci 1964;120:710-28.

10. Derom F, Barbier F, Ringoir S, et al. Ten-month survival after lung homotransplantation in man. J Thorac Cardiovasc Surg 1971;61:835-46.

11. Cooley DA, Bloodwell RD, Hallman GL, et al. Organ transplantation for advanced cardiopulmonary disease. Ann Thorac Surg 1969;8:30-46.

12. Wildevuur CR, Benfield JR. A review of 23 human lung transplantations by 20 surgeons. Ann Thorac Surg 1970;9:489-515.

13. Reitz BA. The first successful combined heart-lung transplantation. J Thorac Cardiovasc Surg 2011;141:867-9.

14. Toronto Lung Transplant Group. Unilateral lung transplantation for pulmonary fibrosis. $\mathrm{N}$ Engl J Med 1986;314:1140-5.

15. Cooper JD, Pearson FG, Patterson GA, et al. Technique of successful lung transplantation in humans. J Thorac Cardiovasc Surg 1987;93:173-81.

16. Mal H, Andreassian B, Pamela F, et al. Unilateral lung transplantation in end-stage pulmonary emphysema. Am
Rev Respir Dis 1989;140:797-802.

17. Starnes VA, Barr ML, Cohen RG. Lobar transplantation. Indications, technique, and outcome. J Thorac Cardiovasc Surg 1994;108:403-10; discussion 410-1.

18. Shinoi K, Hayata Y, Aoki H, et al. Pulmonary lobe homotransplantation in human subjects. Am J Surg 1966;111:617-28.

19. Couetil JP, Tolan MJ, Loulmet DF, et al. Pulmonary bipartitioning and lobar transplantation: a new approach to donor organ shortage. J Thorac Cardiovasc Surg 1997;113:529-37.

20. Couetil JP, Argyriadis PG, Tolan MJ, et al. Contralateral lung transplantation: a left lung implanted in the right thorax. Ann Thorac Surg 2001;72:933-5.

21. Date H, Aoyama A, Hijiya K, et al. Outcomes of various transplant procedures (single, sparing, inverted) in livingdonor lobar lung transplantation. J Thorac Cardiovasc Surg 2017;153:479-86.

22. Chen-Yoshikawa TF, Tanaka S, Yamada Y, et al. Intermediate outcomes of right-to-left inverted livingdonor lobar lung transplantation. Eur J Cardiothorac Surg 2019;56:1046-53.

23. Noirclerc MJ, Metras D, Vaillant A, et al. Bilateral bronchial anastomosis in double lung and heart-lung transplantations. Eur J Cardiothorac Surg 1990;4:314-7.

24. Pasque MK, Cooper JD, Kaiser LR, et al. Improved technique for bilateral lung transplantation: rationale and initial clinical experience. Ann Thorac Surg 1990;49:785-91.

25. Veith FJ, Kamholz SL, Mollenkopf FP, et al. Lung transplantation 1983. Transplantation 1983;35:271-8.

26. Garfein ES, Ginsberg ME, Gorenstein L, et al. Superiority of end-to-end versus telescoped bronchial anastomosis in single lung transplantation for pulmonary emphysema. J Thorac Cardiovasc Surg 2001;121:149-54.

27. Haglin JJ, Ruiz E, Baker RC, et al. Histologic studies of human lung allotransplantation. In: Wildevuur C. editor. Morphology in lung transplantation. Basel: Karger Publishers, 1973:13-22.

28. Couraud L, Baudet E, Martigne C, et al. Bronchial revascularization in double-lung transplantation: a series of 8 patients. Bordeaux Lung and Heart-Lung Transplant Group. Ann Thorac Surg 1992;53:88-94.

29. Daly RC, Tadjkarimi S, Khaghani A, et al. Successful double-lung transplantation with direct bronchial artery revascularization. Ann Thorac Surg 1993;56:885-92.

30. Guzman-Pruneda FA, Orr Y, Trost JG, et al. Bronchial artery revascularization and en bloc lung transplant in 
children. J Heart Lung Transplant 2016;35:122-9.

31. Pettersson GB, Yun JJ, Nørgaard MA. Bronchial artery revascularization in lung transplantation: techniques, experience, and outcomes. Curr Opin Organ Transplant 2010;15:572-7.

32. Tong MZ, Johnston DR, Pettersson GB. The role of bronchial artery revascularization in lung transplantation. Thorac Surg Clin 2015;25:77-85.

33. Kortz AB. Experimental bilateral transsternal thoracotomy: factors improving survival. J Thorac Surg 1958;35:305-8.

34. Hartwig MG, Walczak R, Lin SS, et al. Improved survival but marginal allograft function in patients treated with extracorporeal membrane oxygenation after lung transplantation. Ann Thorac Surg 2012;93:366-71.

35. Bermudez CA, Adusumilli PS, McCurry KR, et al. Extracorporeal membrane oxygenation for primary graft dysfunction after lung transplantation: long-term survival. Ann Thorac Surg 2009;87:854-60.

36. Biscotti M, Sonett J, Bacchetta M. ECMO as bridge to lung transplant. Thorac Surg Clin 2015;25:17-25.

37. Hoopes CW, Kukreja J, Golden J, et al. Extracorporeal membrane oxygenation as a bridge to pulmonary transplantation. J Thorac Cardiovasc Surg 2013;145:8627; discussion 867-8.

38. Rehder KJ, Turner DA, Hartwig MG, et al. Active rehabilitation during extracorporeal membrane oxygenation as a bridge to lung transplantation. Respir Care 2013;58:1291-8.

39. Veith FJ. Lung transplantation. Transplant Proc 1977;9:203-8.

40. Pereszlenyi A, Lang G, Steltzer H, et al. Bilateral lung transplantation with intra- and postoperatively prolonged ECMO support in patients with pulmonary hypertension. Eur J Cardiothorac Surg 2002;21:858-63.

41. Ius F, Kuehn C, Tudorache I, et al. Lung transplantation on cardiopulmonary support: venoarterial extracorporeal membrane oxygenation outperformed cardiopulmonary bypass. J Thorac Cardiovasc Surg 2012;144:1510-6.

42. Bermudez CA, Shiose A, Esper SA, et al. Outcomes of intraoperative venoarterial extracorporeal membrane oxygenation versus cardiopulmonary bypass during lung transplantation. Ann Thorac Surg 2014;98:1936-42; discussion 1942-3.

43. Egan TM, Lambert CJ Jr, Reddick R, et al. A strategy to increase the donor pool: use of cadaver lungs for transplantation. Ann Thorac Surg 1991;52:1113-20; discussion 1120-1.

44. Love RB, Stringham JC, Chomiak PN, et al. Successful lung transplantation using a non-heart-beating donor. J Heart Lung Transplant 1995; 14:abstr S88.

45. D'Alessandro AM, Hoffmann RM, Knechtle SJ, et al. Controlled non-heart-beating donors: a potential source of extrarenal organs. Transplant Proc 1995;27:707-9.

46. Cypel M, Levvey B, Van Raemdonck D, et al. International Society for Heart and Lung Transplantation Donation After Circulatory Death Registry Report. J Heart Lung Transplant 2015;34:1278-82.

47. Sabashnikov A, Patil NP, Popov AF, et al. Long-term results after lung transplantation using organs from circulatory death donors: a propensity score-matched analysis $†$. Eur J Cardiothorac Surg 2016;49:46-53.

48. Robicsek F, Sanger PW, Taylor FH. Simple method of keeping the heart "alive" and functioning outside of the body for prolonged periods. Surgery 1963;53:525-30.

49. Robicsek F, Tam W, Daugherty HK, et al. The stabilized autoperfusing heart-lung preparation as a vehicle for extracorporeal preservation. Transplant Proc 1969;1:834-9.

50. Hardesty RL, Griffith BP. Autoperfusion of the heart and lungs for preservation during distant procurement. J Thorac Cardiovasc Surg 1987;93:11-8.

51. Steen S, Sjöberg T, Pierre L, et al. Transplantation of lungs from a non-heart-beating donor. Lancet 2001;357:825-9.

52. Cypel M, Yeung JC, Liu M, et al. Normothermic ex vivo lung perfusion in clinical lung transplantation. N Engl J Med 2011;364:1431-40.

53. Van Raemdonck D, Keshavjee S, Levvey B, et al. Donation after circulatory death in lung transplantation-five-year follow-up from ISHLT Registry. J Heart Lung Transplant 2019;38:1235-45.

54. Cypel M, Keshavjee S. Extending the donor pool: rehabilitation of poor organs. Thorac Surg Clin 2015;25:27-33.

55. Machuca TN, Mercier O, Collaud S, et al. Lung transplantation with donation after circulatory determination of death donors and the impact of ex vivo lung perfusion. Am J Transplant 2015;15:993-1002.

56. Inci I, Yamada Y, Hillinger S, et al. Successful lung transplantation after donor lung reconditioning with urokinase in ex vivo lung perfusion system. Ann Thorac Surg 2014;98:1837-8.

57. Makdisi G, Wozniak TC. How to establish a successful ex vivo lung perfusion program. Ann Transl Med 2017;5:S12.

58. Makdisi G, Makdisi T, Jarmi T, et al. Ex vivo lung perfusion review of a revolutionary technology. Ann Transl Med 2017;5:343. 
59. Warnecke G, Moradiellos J, Tudorache I, et al. Normothermic perfusion of donor lungs for preservation and assessment with the Organ Care System Lung before bilateral transplantation: a pilot study of 12 patients. Lancet 2012;380:1851-8.

60. Warnecke G, Van Raemdonck D, Smith MA, et al. Normothermic ex-vivo preservation with the portable Organ Care System Lung device for bilateral lung transplantation (INSPIRE): a randomised, open-label, non-inferiority, phase 3 study. Lancet Respir Med 2018;6:357-67.

61. Loor G, Warnecke G, Villavicencio MA, et al. Portable normothermic ex-vivo lung perfusion, ventilation, and functional assessment with the Organ Care System on donor lung use for transplantation from extended-criteria donors (EXPAND): a single-arm, pivotal trial. Lancet Respir Med 2019;7:975-84.

62. Available online: https://www.accessdata.fda.gov/cdrh_ docs/pdf16/P160013S002A.pdf

63. Billingham RE, Krohn PL, Medawar PB. Effect of cortisone on survival of skin homografts in rabbits. Br Med J 1951;1:1157-63.

64. Hume DM, Merrill JP, Miller BF, et al. Experiences with renal homotransplantation in the human: report of nine cases. J Clin Invest 1955;34:327-82.

65. Goodwin WE, Mims MM, Kaufman JJ. Human renal transplantation III. Technical problems encountered in six cases of kidney homotransplantation. Trans Am Assoc Genitourin Surg 1962;54:116-25.

66. Goodwin WE, Kaufman JJ, Mims MM, et al. Human renal transplantation. I. Clinical experiences with six cases of renal homotransplantation. J Urol 1963;89:13-24.

67. Starzl TE, Marchioro TL, Waddell WR. The reversal of rejection in human renal homografts with subsequent development of homograft tolerance. Surg Gynecol Obstet 1963;117:385-95.

68. Dempster WJ. Kidney homotransplantation. Br J Surg 1953;40:447-65.

69. Dempster WJ. The effects of cortisone on the homotransplanted kidney. Arch Int Pharmacodyn Ther 1953;95:253-82.

70. Hamburger J, Vaysse J, Crosnier J, et al. Renal homotransplantation in man after radiation of the recipient. Experience with six patients since 1959. Am J Med 1962;32:854-71.

71. Kuss R, Legrain M, Mathe G, et al. Homologous human kidney transplantation. Experience with six patients. Postgrad Med J 1962;38:528-31.
72. Elion GB. The George Hitchings and Gertrude Elion Lecture. The pharmacology of azathioprine. Ann N Y Acad Sci 1993;685:400-7.

73. Schwartz R, Dameshek W. The effects of 6-mercaptopurine on homograft reactions. J Clin Invest 1960;39:952-8.

74. Zukoski CF, Lee HM, Hume DM. The prolongation of functional survival of canine renal homografts by 6-mercaptopurine. Surg Forum 1960;11:470-2.

75. Calne RY. The rejection of renal homografts. Inhibition in dogs by 6-mercaptopurine. Lancet 1960;1:417-8.

76. Murray JE, Merrill JP, Harrison JH, et al. Prolonged survival of human-kidney homografts by immunosuppressive drug therapy. $\mathrm{N}$ Engl J Med 1963;268:1315-23.

77. Starzl TE, Brettschneider L, Penn I, et al. A trial with heterologous antilymphocyte globulin in man. Transplant Proc 1969;1:448-54.

78. Dreyfus M, Haerri E, Hoffman H, et al. Cyclosporin A and C, new metabolites from trichoderma polysporum. Eur J Appl Microbiol 1976;3:125-33.

79. Borel JF, Feurer C, Gubler HU, et al. Biological effects of cyclosporin A: a new antilymphocytic agent. Agents Actions 1976;6:468-75.

80. Borel JF. History of the discovery of cyclosporin and of its early pharmacological development. Wien Klin Wochenschr 2002;114:433-7.

81. Colombo D, Ammirati E. Cyclosporine in transplantation - a history of converging timelines. J Biol Regul Homeost Agents 2011;25:493-504.

82. Heusler K, Pletscher A. The controversial early history of cyclosporin. Swiss Med Wkly 2001;131:299-302.

83. Hausen B, Morris RE. Review of immunosuppression for lung transplantation. Novel drugs, new uses for conventional immunosuppressants, and alternative strategies. Clin Chest Med 1997;18:353-66.

84. Hachem RR, Yusen RD, Chakinala MM, et al. A randomized controlled trial of tacrolimus versus cyclosporine after lung transplantation. J Heart Lung Transplant 2007;26:1012-8.

85. Treede H, Glanville AR, Klepetko W, et al. Tacrolimus and cyclosporine have differential effects on the risk of development of bronchiolitis obliterans syndrome: results of a prospective, randomized international trial in lung transplantation. J Heart Lung Transplant 2012;31:797-804.

86. Zuckermann A, Reichenspurner H, Birsan T, et al. Cyclosporine A versus tacrolimus in combination with mycophenolate mofetil and steroids as primary 
immunosuppression after lung transplantation: one-year results of a 2-center prospective randomized trial. J Thorac Cardiovasc Surg 2003;125:891-900.

87. McDermott JK, Girgis RE. Individualizing immunosuppression in lung transplantation. Glob Cardiol Sci Pract 2018;2018:5.

88. Trulock EP, Christie JD, Edwards LB, et al. Registry of the International Society for Heart and Lung Transplantation: twenty-fourth official adult lung and heart-lung transplantation report-2007. J Heart Lung Transplant 2007;26:782-95.

89. Chambers DC, Cherikh WS, Harhay MO, et al. The International Thoracic Organ Transplant Registry of the International Society for Heart and Lung Transplantation: Thirty-sixth adult lung and heartlung transplantation Report-2019; Focus theme: Donor and recipient size match. J Heart Lung Transplant 2019;38:1042-55.

90. Glanville AR, Verleden GM, Todd JL, et al. Chronic lung allograft dysfunction: Definition and update of restrictive allograft syndrome-A consensus report from the Pulmonary Council of the ISHLT. J Heart Lung Transplant 2019;38:483-92.

91. Verleden GM, Glanville AR, Lease ED, et al. Chronic lung allograft dysfunction: Definition, diagnostic criteria, and approaches to treatment-A consensus report from the Pulmonary Council of the ISHLT. J Heart Lung Transplant 2019;38:493-503.

92. Parulekar AD, Kao CC. Detection, classification, and management of rejection after lung transplantation. J Thorac Dis 2019;11:S1732-9.

93. Tissot A, Danger R, Claustre J, et al. Early Identification of Chronic Lung Allograft Dysfunction: The Need of Biomarkers. Front Immunol 2019;10:1681.

94. Luijk B, Vos R, van Moorsel CHM. Precision medicine: integration of genetics and functional genomics in prediction of bronchiolitis obliterans after lung transplantation. Curr Opin Pulm Med 2019;25:308-16.

95. Weigt SS, Wang X, Palchevskiy V, et al. Gene Expression Profiling of Bronchoalveolar Lavage Cells Preceding a Clinical Diagnosis of Chronic Lung Allograft Dysfunction. PLoS One 2017;12:e0169894.

96. Royer PJ, Baron D, Reboulleau D, et al. Blood mRNA and miRNA transcriptome to predict chronic lung allograft dysfunction. Eur Respir J 2015;46:PA1792.

97. Veraar C, Kliman J, Benazzo A, et al. Potential novel biomarkers for chronic lung allograft dysfunction and azithromycin responsive allograft dysfunction. Sci Rep
2021;11:6799.

98. Kastelijn EA, van Moorsel CH, Ruven HJ, et al. Genetic polymorphisms and bronchiolitis obliterans syndrome after lung transplantation: promising results and recommendations for the future. Transplantation 2012;93:127-35.

99. Available online: https://unos.org/transplant/history/ (Accessed on 08/12/2021).

100. Available online: https://www.afdt.org/about/about-afdt (Accessed on 08/12/2021).

101.Available online: https://uscode.house.gov/view.xhtml?h l=false\&edition=prelim\&req=granuleid $\% 3$ AUSC-2014title42-section274\&num=0 (Accessed on 08/12/2021).

102.Edwards E. 1991 Center Specific Graft and Patient Survival Rates. Washington: US Dept of Health and Human Services; Richmond: United Network for Organ Sharing; 1992.

103. Burdick J, Norman DJ, Hunsicker L, et al. Identification of poorly performing transplant centers using the UNOS center-specific data. Transplant Proc 1997;29:1495.

104.Egan TM, Murray S, Bustami RT, et al. Development of the new lung allocation system in the United States. Am J Transplant 2006;6:1212-27.

105. Valapour M, Lehr CJ, Skeans MA, et al. OPTN/SRTR 2017 Annual Data Report: Lung. Am J Transplant 2019;19 Suppl 2:404-84.

106.Egan TM, Edwards LB. Effect of the lung allocation score on lung transplantation in the United States. J Heart Lung Transplant 2016;35:433-9.

107. Gottlieb J, Smits J, Schramm R, et al. Lung Transplantation in Germany Since the Introduction of the Lung Allocation Score. Dtsch Arztebl Int 2017;114:179-85.

108. Boussaud V, Mal H, Trinquart L, et al. One-year experience with high-emergency lung transplantation in France. Transplantation 2012;93:1058-63.

109.Available online: https://optn.transplant.hrsa.gov/ media/4206/bp_202012_updated-cohort-for-calculationof-the-lung-allocation-score.pdf

110.Available online: https://optn.transplant.hrsa.gov/ media/4569/refine-lung-data-fields.pdf

111.Available online: https://optn.transplant.hrsa.gov/ resources/allocation-calculators/las-calculator/ (accessed on $7 / 29 / 2021$ ).

112. Leard LE, Holm AM, Valapour M, et al. Consensus document for the selection of lung transplant candidates: An update from the International Society for Heart and Lung Transplantation. J Heart Lung Transplant 2021;40:1349-79. 
113.Available online: https://humboldtcanada.com/ presentations_air/chow.pdf (accessed on 8/12/2021).

114. Maurer JR, Frost AE, Estenne M, et al. International guidelines for the selection of lung transplant candidates. The International Society for Heart and Lung Transplantation, the American Thoracic Society, the American Society of Transplant Physicians, the European Respiratory Society. J Heart Lung Transplant 1998;17:703-9.

115. Orens JB, Estenne M, Arcasoy S, et al. International guidelines for the selection of lung transplant candidates:

doi: $10.21037 /$ ccts-21-11

Cite this article as: Makdisi G, Cedeño-Rodríguez AR. Narrative review of the evolution of lung transplant. Curr Chall Thorac Surg 2021.
2006 update--a consensus report from the Pulmonary Scientific Council of the International Society for Heart and Lung Transplantation. J Heart Lung Transplant 2006;25:745-55.

116. Weill D, Benden C, Corris PA, et al. A consensus document for the selection of lung transplant candidates: 2014--an update from the Pulmonary Transplantation Council of the International Society for Heart and Lung Transplantation. J Heart Lung Transplant 2015;34:1-15.

(English Language Editor: K. Brown) 